\title{
Evaluasi Seminar Nasional Online, Program Bermain Bersama Anak Selama Masa Pandemi Covid 19
}

\author{
Diah Andika Sari ${ }^{1}$, Tiara Astari ${ }^{2}$, Ika Yulianingsih ${ }^{3}$, Nova Nur Cahyanti ${ }^{4}$, Siti \\ Sarah 5 \\ 1,2,4,5 Pendidikan Guru Pendidikan Anak Usia Dini, Fakultas Ilmu Pendidikan, Universitas \\ Muhammadiyah Jakarta \\ ${ }^{3}$ Pendidikan Olahraga, Fakultas Ilmu Pendidikan, Universitas Muhammadiyah Jakarta \\ e-mail corresponden: diahmursil@gmail.com
}

\begin{abstract}
ABSTRAK. Sejak diberlakukannya pembatasan sosial berskala besar (PSBB) oleh pemerintah pada 16 Maret 2020, para ibu berfungsi ganda menjadi ibu guru bagi anaknya dirumah. Seminar online ini diadakan untuk memberikan panduan kepada ibu, untuk melakukan kegiatan bermain bersama anaknya selama dirumah saja. Tujuan penelitian ini adalah untuk mengevaluasi apakah seminar nasional online tentang "Program Bermain Bersama Anak Selama Dirumah Saja" berdampak positif terhadap peserta dan juga lembaga penyelenggara. Sampel berjumlah 244 orang yang mengisi angket evaluasi dari 779 peserta. Metoda evaluasi yang digunakan adalah metode penelitian evaluasi dari Kickpatrick pada level 1dan level 2. Pada level 1, Reaksi peserta terkait dengan 1) Penyelenggaraan, meliputi (a) kepesertaan, seperti kejelasan informasi kegiatan, kemudahan akses kepesertaan (b) kepanitiaan, manajemen waktu kegiatan(c) akomodasi, seperti: pemberian materi dan sertifikat, kesesuaian materi dengan harapan, 2) Pemateri, meliputi a) materi pemaparan presentasi, b) isi materi, c)kesesuaian materi dengan issue, d) kebermanfaatan materi dan e) cara menjelaskan dari pemateri. Dari hasil penelitian didapatkan reaksi yang sangat positif dari peserta. Hampir semua peserta ingin mengikuti jika diselenggarakan kegiatan selanjutnya. Sedangkan hasil pada level 2, pengetahuan peserta, dari hasil perbandingan pre test dan post test terhadap materi seminar didapatkan peningkatan pengetahuan para peserta tentang bermain bersama anak dirumah.
\end{abstract}

Kata Kunci: Seminar Online, Program Bermain Bersama Anak, Covid-19

ABSTRACT. Since the enactment of large-scale social restrictions (PSBB) by the government on March 16, 2020, mothers have the dual function of becoming teachers for their children at home. This online national seminar was held to provide guidance to mothers, to play with their children while at home. The purpose of this study was to evaluate whether the online national seminar on "Playing Program with Children During stay at Home" had a positive reaction from participants as well for organizers. Sample of 244 people filled out the evaluation questionnaire of 779 participants. The evaluation method used was the training evaluation method from Kickpatrick at level 1 and level 2. At level 1, participants' reactions were related to 1) Organization, including (a) participation, such as clarity of information on activities, ease of access to participation (b) committee, time management of activities (c) accommodation, such as: provision of material and certificates, conformity of material with expectations, 2) Presenters, including a) presentation material, b) content of material, c) material suitability with issue, d) usefulness of material and e) how presenters delivered the material. From the 
research results obtained a very positive reaction from the participants. Almost all participants want to follow if further activities will hold. While the results at level 2 , the participants 'knowledge, from the comparison of pre-test and post-test to the seminar material found an increased in the participants' knowledge about playing with children at home.

Keyword: Online Seminar, Playing Program With Children, Covid-19

\section{PENDAHULUAN}

Dari hasil survey yang dilakukan oleh Diah Andika Sari, didapatkan bahwa menghadapi situasi pandemi covid 19 ini, dari 545 ibu yang tersebar diseluruh Indonesia, didapatkan data bahwa ibu merasa kurang siap untuk bermain bersama anak sepanjang hari dan setiap hari selama masa PSBB. Ibu merasakan kebingungan untuk bermain bersama anak, karena dirumah setiap hari, dan sepanjang hari. Selain itu ibu juga merasa lelah, bosan, dan kurang sabar, karena banyaknya pekerjaan lain yang harus dilakukan selain mengurus anak. Hal ini sepertinya sesuai dengan fenomena yang kita lihat sehari-hari. Baik berdasarkan hasil obrolan santai dengan ibu-ibu, maupun celotehan para ibu di sosial media[1].

Survei sebelumnya di Pondok Aren, Tangerang Selatan, memperlihatkan 43\% bahwa ibu ada di rumah saat anaknya bangun tidur, dan pulang kerumah sewaktu anak telah tidur. Artinya intensitas waktu interaksi antara ibu dan anak sangat kecil. Kondisi pandemi Covid-19 ini tentunya mengubah ritme kegiatan ibu dan menyebabkan saat ini ibu berada dirumah sepanjang hari dan setiap hari[2]. Penelitian lainnya di TK Masyitoh 1, Purworejo terlihat bahwa keterlibatan orangtua yang rendah dalam pendidikan anak karena beberapa hal, seperti kesibukan orangtua, pengetahuan orangtua yang kurang terhadap kegiatan pendidikan disekolah. Selain itu juga adanya anggapan bahwa pendidikan merupakan tanggungjawab sekolah [3]. Selama ini ibu nyaris menerima anak sudah dalam keadaan masa istirahat mereka. Sangat sedikit waktu ibu untuk melakukan kegiatan atau bermain bersama anak. Dengan adanya pandemi covid 19, dimana semua annggota masyarakat harus bekerja, belajar dan beribadah dirumah saja, otomatis selain bekerja, melakukan pekerjaan rumahtangga lainnya, ibu juga harus berperan ganda menjadi guru. Hal ini tentunya merupakan keadaan yang bertolak belakang dari data keadaan sebelumnya.

Keluarga adalah unit terkecil dari masyarakat yang akan melahirkan generasi penerus dan sebagai penentu nasib bangsa. Keluarga yang dapat menjalankan fungsinya dengan baik, akan melahirkan generasi yang berkualitas untuk kekuatan dan kemajuan bangsa. Begitu juga sebaliknya, jika keluarga tidak berfungsi dengan baik, akan timbul generasi yang menjadi masalah bagi bangsa. [4]. Hal ini memperlihatkan bahwa covid 19 mengembalikan keluarga pada fungsi aslinya. Hanya saja kesiapan orangtua, khususnya ibu, perlu diperhatikan. Bermain dapat meningkatkan kelekatan antara ibu dan anak. Untuk meningkatkan kemampuan ibu bermain bersama anak perlu dilakukan pelatihan. Dari hasil penelitian didapatkan bahwa ibu yang mendapatkan pelatihan bermain bersama anak, mengalami peningkatan kelekatan[5]. Peran orang tua untuk membimbing anaknya selama masa pandemi dirumah saja memperat hubungan ibu dan 
anak, dimana dengan membimbing anaknya sendiri selama dirumah orangtua dapat melihat perkembangan anaknya secara langsung[6].

Esensi bermain bagi anak usia dini antara lain: 1) merupakan kemauan diri sendiri dan tanpa paksaan; 2) kegiatan aktif yang melibatkan keseluruhan anak ; 3) melakukan sesuatu sesuai keinginan, dan 4) tidak ada tujuankecuali ingin berpartisipasi[7]. Bermain merupakan kebutuhan bagi anak, karena itu orangtua harus mengetahui bagaimana peran bermain untuk mengembangkan perkembangan anak secara optimal [8]. Peran orang tua untuk bermain bersama anak lebih kepada kegiatan pendampingan bagi orangtua selama melakukan kegiatan dirumah[9].

Pentingnya bermain bagi anak dan ibu selama dirumah, dan juga pengetahuan ibu untuk melakukan kegiatan bermain bersama anak di rumah menjadi landasan dilakukannya kegiatan seminar nasional on line yang terbuka untuk masyarakat luas akibat dampak dari masa pandemic covid-19. Serial seminar on line ini adalah kerjasama antara Prodi PG PAUD Universitas Muhammadiyah Jakarta dengan beberapa prodi PG PAUD lainnya di Indonesia yaitu Universitas Ibnu Khaldun Bogor, Universitas Muhammadiyah Jember, Universitas Negeri Makasar, Universitas Negeri Jakarta, Universitas Islam Jember, STBAN Sriwijaya Tangerang, dan juga didukung oleh Ikatan Doktor PAUD Indonesia (IKAD PAUDI). Kegiatan seminar nasional on line ber-seri ini di koordinir oleh Yayasan Gema Anak Indonesia, dengan tema "Belajar menyenangkan selama pandemi covid-19". Seminar nasional on line dilakukan selama 4 hari, yaitu pada hari Sabtu dan Minggu, pada tanggal 20, 21, 27, dan 28 Juni 2020. Dimulai pukul 08.00 15.00. Ada 10 topik yang saling berkesinambungan pada seminar nasional ber-seri ini. Materi "Program Bermain Bersama Anak selama Pandemi Covid-19" merupakan salah satu dari 10 materi seminar. Tujuan dari materi ini adalah agar para ibu/peserta mempunyai referensi bagaimana membuat program untuk melakukan kegiatan bermain bersama anak selama dirumah saja. Sedangkan evaluasi kegiatan ini bertujuan untuk melihat bagaimana reaksi dari para peserta tentang pelaksanaan kegiatan seminar on line pada topik ini. Selain itu juga untuk melihat bagaimana pengetahuan peserta tentang materi seminar on line dengan topik tersebut. Apakah penetahuan mereka mengalami peningkatan, sehingga tujuan dari kegiatan seminar ini untuk memberikan panduan bagaimana membuat program bermain bersama anak dapat tercapai, sekaligus sebagai gambaran untuk melakukan kegiatan selanjutnya.

\section{METODE}

Metode evaluasi kegiatan yang dilakukan adalah dengan menggunakan metode evaluasi Kircpatrick. Metode evaluasi Kirckpatrick terdiri dari 4 level, yaitu level 1) Reaksi peserta, level 2) pengetahuan peserta, level 3) perilaku peserta, dan level 4) dampak dari kegiatan[10]. Penelitian evaluasi kegiatan seminar nasional online program bermain bersama anak selama masa pandemi covid-19 ini hanya mengevaluasi pada level 1, dan level 2. Pada penilaian level 1, terkait dengan reaksi peserta yang meliputi 1) Penyelenggaraan, yaitu (a) kepesertaan, seperti kejelasan informasi kegiatan, kemudahan akses kepesertaan (b) kepanitiaan, manajemen waktu kegiatan(c) 
akomodasi, seperti: pemberian materi dan sertifikat, kesesuaian materi dengan harapan, serta motivasi kepersertaan untuk kegiatan selanjutnya. 2) Penilaian terhadap pemateri, meliputi a) materi pemaparan presentasi, b) isi materi, c)kesesuaian materi dengan issue, d) kebermanfaatan materi dan e) cara menjelaskan dari pemateri. Sedangkan pada level 2, meliputi pengetahuan peserta tentang materi kegiatan, yang dilihat dari hasil perbandingan pre test dan post test terhadap materi. Peserta seminar online ini terdiri dari 779 orang, yang terbagi pada pada zoom meeting dan juga live you tube. Sosialisasi kegiatan seminar on line dilakukan dengan penyebaran flyer kegiatan pada whatsapp broadcast, Instagram, dan facebook. Flyer berisikan informasi tentang kegiatan, narasumber, waktu kegiatan, dan cara kepesertaan. Pada flyer juga dicantumkan tautan pendaftaran peserta yang dilakukan dengan menggunakan link yang langsung tersambung dengan whatsapp group. Flyer disebarkan seminggu (7 hari) sebelum kegiatan dilaksanakan. Di group ini semua informasi kegiatan dan juga soal serta angket diberikan kepada peserta. Terdapat 2 whatsapp group yang tebentuk, dengan total anggota 486 orang. Sedangkan sisanya 193 peserta lainnya tidak bergabung di whatsapp group dan mengikuti dari live youtube. Untuk melakukan evaluasi pada level 1, yaitu reaksi, para responden diminta untuk memberikan pendapat mereka tentang penyelenggaraan seminar online. Evaluasi pelaksanaan seminar on line meliputi materi seminar dan pemateri seminar. Sedangkan pada level 2, pengetahuan, peserta diminta untuk mengisi pre test, sebelum kegiatan dilakukan. Sampel yang diambil adalah 244 orang. Sesuai dengan jumlah peserta yang mengisi lembaran evaluasi terhadap tes yang diberikan, baik sebelum dilakukan seminar online (pre test), maupun tes yang diberikan sesudah pelaksanaan seminar online (post test). Jumlah soal pada pre test dan post test ada 10 buah. Bentuk soal pada pre dan post test adalah sama utuk mengukur kemajuan pengetahuan dari peserta, dan berupa soal pilihan ganda. Teknik pengumpulan data dilakukan dengan pemberian google form, kemudian data diolah menggunakan program excel dengan cara persetase. Hasil data lalu dibuatkan tabelnya agar dapat di deskripsikan dan di interpretasikan dengan lebih mudah.

\section{HASIL DAN PEMBAHASAN}

\section{Kegiatan Pelaksanaan Seminar Online}

Seminar online dilakukan pada hari Sabtu, 20 Juni 2020. Mulai pukul 08.0 0sampai pukul 13.00. Link zoom dibuka 30 menit sebelum acara dimulai. Acara dibuka oleh pembawa acara dengan pembacaan doa, dan menyanyikan lagu Indonesia Raya. Kesempatan pertama diberikan kepada key note speaker, yaitu ibu Dr. Yessy Gusman, dari Ikatan Doktor PAUD Indonesia. Sesi pertama adalah materi pembuka dengan tema "Mempersiapkan Anak Menuju Sukses". Sebagai pengantar bahwa kesuksesan bagi anak usia dini itu adalah berbeda-beda dari bergai sudut pandang. Selanjutnya materi program bermain bersama anak selama dirumah saja sampai pukul 11.30. Dilanjutkan dengan tanya jawab dan mencoba membuat program bermain sampai berakhir pada pukul 13.00. Sesuai dengan pertanyaan peserta yaitu bagaimana melakukan kegiatan 
bermain bersama anak, dan bagaimana mengatasi kebingungan orangtua untuk melakukan kegiatan bermain bersama anak.

\section{Profil Peserta}

Jumlah peserta seminar nasional on line ini terdiri dari 779 orang. Peserta berasal dari berbagai wilayah di Indonesia. Mulai dari Aceh, sampai Ambon dan Gorontalo.

Domisili:

779 responses

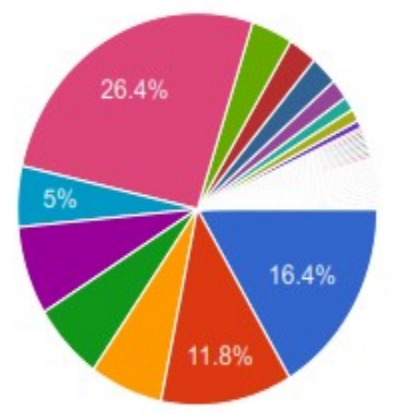

Jabodetabek

Jawa Barat

Jawa Timur

Banten

Sumatra

Kalimantan

Indonesia Timur (Sulawesi, A...

Dompu Nusa Tenggara Barat

A $1 / 8 \nabla$

Gambar 1. Domisili Peserta

Dari hasil survei didapatkan bahwa 80,6\% dari peserta mendapatkan informasi kegiatan seminar nasional on line ini dari whatsapp broadcast.

\section{Dari mana Anda mengetahui kegiatan ini:}

779 responses

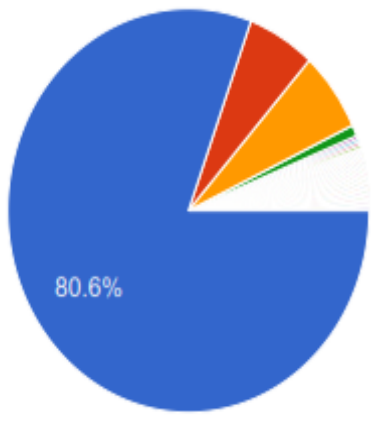

Whatapps Broadcast

Facebook

Instagram

Teman

Dosen

HIMPAUDI

Dari teman

Group whatsapp

$\Delta 1 / 6 \boldsymbol{\nabla}$

Gambar 2. Sumber Informasi kegiatan

Usia peserta secara merata dimulai dari usia 20 tahun. Pendidikan peserta $51,7 \%$ nya adalah sarjana. Terdapat $28,3 \%$ yang sudah master dan juga doktor. Hanya $20 \%$ dari peserta yang berpendidikan SMA dan sederajat. Pekerjaan peserta didominasi oleh guru dan dosen sebanyak $77,2 \%$, dan mahasiswa $11,3 \%$, sedangkan sisanya lain- 
lain 11,5\% nya lain-lain. Motivasi peserta 45,1\% adalah untuk meningkatkan pengetahuan dan wawasan. Sedangkan 49,8\% lainnya selain untuk meningkatkan pengetahuan dan wawasan, juga untuk meningkatkan keterampilan, dan sekaligus untuk mendapatkan sertifikat. Sisanya 5,1\% mengisi lain-lain. Sehingga bisa disimpulkan bahwa whatsapp broadcast adalah media yang sangat efektif untuk menyampaikan informasi dengan jangkauan yang sangat luas. Tapi karena sosialisasi di sampaikan dan didapat dari group-group yang biasanya berisikan anggota yang homogen, maka responden ataupun peserta yang didapatkan juga otomatis nyaris homogen dilihat dari sisi usia, pendidikan, dan juga jenis pekerjaan.

\section{Evaluasi Level 1. Reaksi Peserta}

\section{Evaluasi Pelaksanaan Seminar Online}

Untuk melihat reaksi kepuasan dari peserta diberikan beberapa pertanyaan yang mencakup: 1) Reaksi Peserta Terhadap Penyelenggaraan seminar online. Tujuan dari evaluasi terhadap reaksi peserta tehadap penyelenggaraan seminar online ini adalah untuk mengetahui kepuasan peserta seminar online terhadap keberhasilan proses kegiatan pembelajaran yang terkait dengan (a) kepesertaan, seperti kejelasan informasi kegiatan, kemudahan akses kepesertaan (b) kepanitiaan, meliputi manajemen waktu kegiatan(c) akomodasi, meliputi pemberian materi dan sertifikat kepada peserta, kesesuaian materi dengan harapan, serta motivasi kepersertaan untuk kegiatan selanjutnya. Sedangkan yang ke 2) Reaksi peserta terhadap pemateri kegiatan seminar on line. Reaksi peserta tersebut dapat dijelaskan secara rinci seperti berikut:

\section{1) Reaksi Peserta Terhadap Penyelenggaraan seminar online.}

Dari gambar 2 berikut terlihat bahwa informasi kegiatan yang terdapat pada flyer kegiatan tentang tema kegiatan, waktu kegiatan, narasumber kegiatan sudah jelas dan mendapatkan penilaian dari baik sampai dengan sangat baik. Tidak ada responden yang menilai flyer informasi kegiatan tersebut pada nilai cukup maupun kurang.

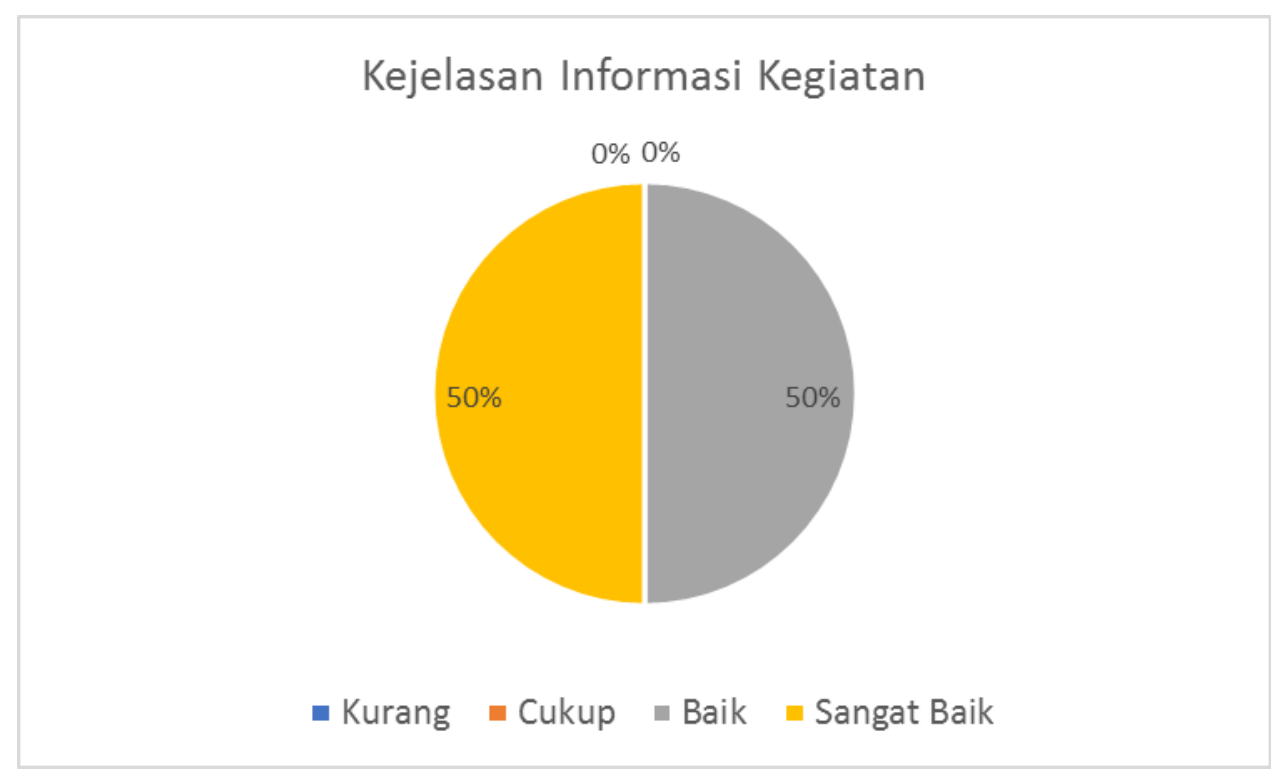

Gambar.2 Kejelasan informasi Kegiatan

Sedangkan gambar 3 memperlihatkan bahwa akses informasi kegiatan mudah didapatkan. Bisa dilihat bahwa $71 \%$ peserta menilai akses informasi untuk menjadi 
peserta sangat mudah untuk diakses. Artinya penyebaran flyer sekaligus whatsapp broadcast yang langsung memberikan tautan ke whatsapp group sangat efektif untuk mengumpulkan peserta menjadi satu, agar semua informasi dapat dibagikan di group tersebut.

\section{Kemudahan akses informasi Kepesertaan}

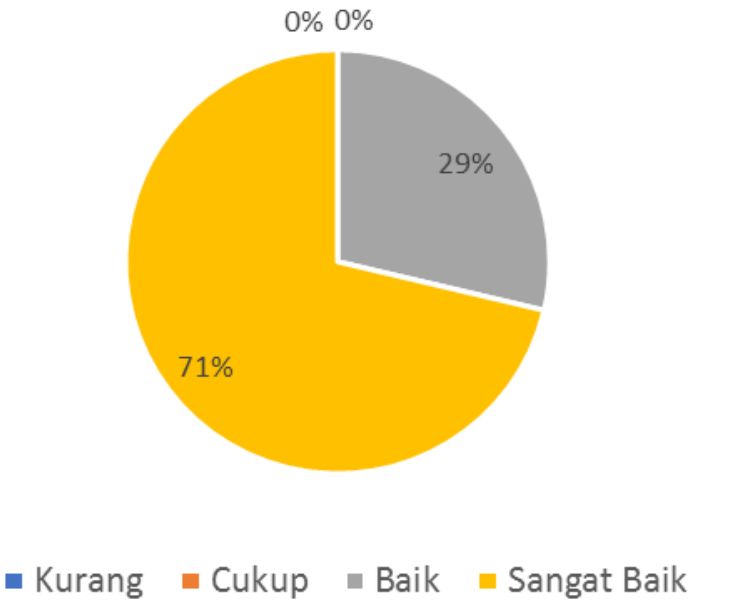

Gambar.3 Kemudahan Akses Informasi Kepesertaan

Gambar 4 berikut ini memperlihatkan respon peserta tentang manajemen waktu pelaksanaan kegiatan seminar nasional on line. Kegiatan dilaksanakan sesuai dengan jadual yang sudah ditetapkan dan diumumkan di whatsapp group. Sehingga $78 \%$ peserta menilai manajemen waktu pelaksanaan kegiatan seminar nasional on line ini sudah sangat baik.

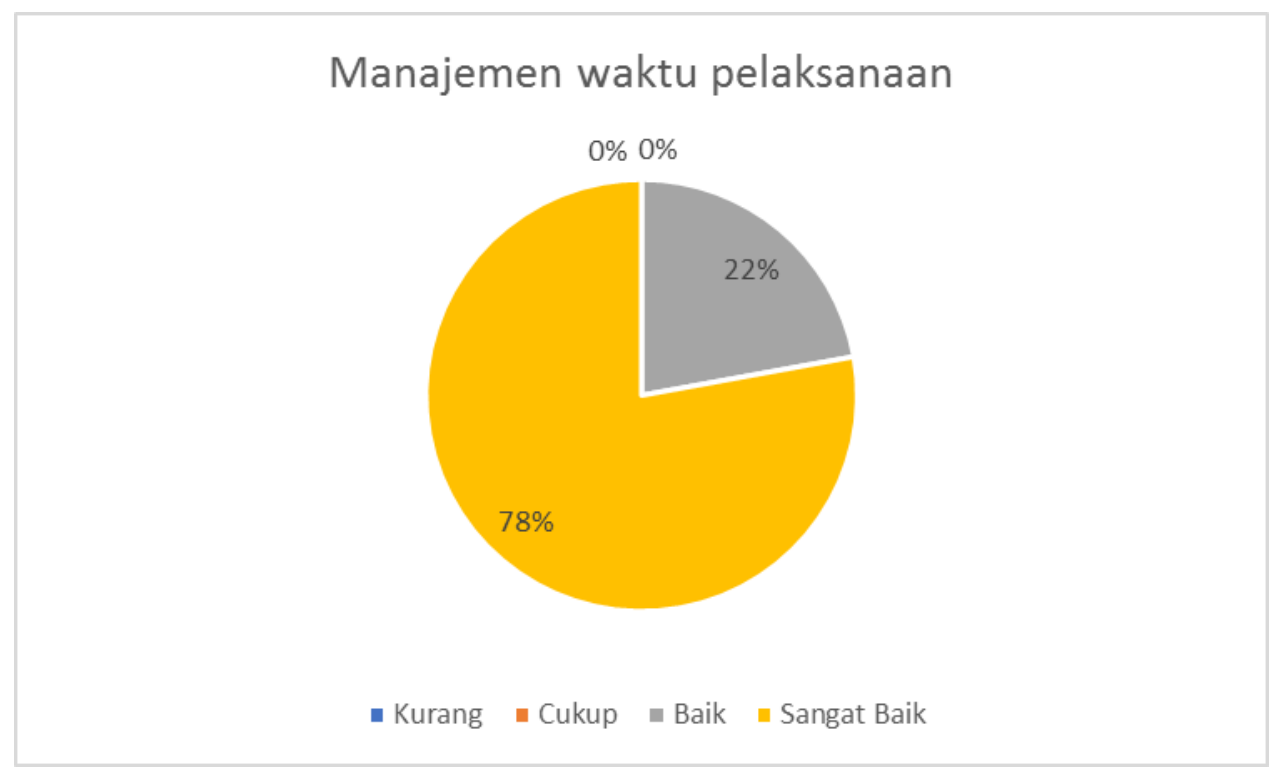

Gambar.4. Manajemen waktu pelaksanaan

Kegiatan seminar nasional on line ini selain diberikan secara gratis, panitia juga memberikan fasilitas kepada peserta berupa soft copy materi kegiatan seminar, dan juga 
sertifikat kegiatan. Sehingga $82 \%$ dari peserta menilai fasilitas yang diberikan sudah sangat baik.

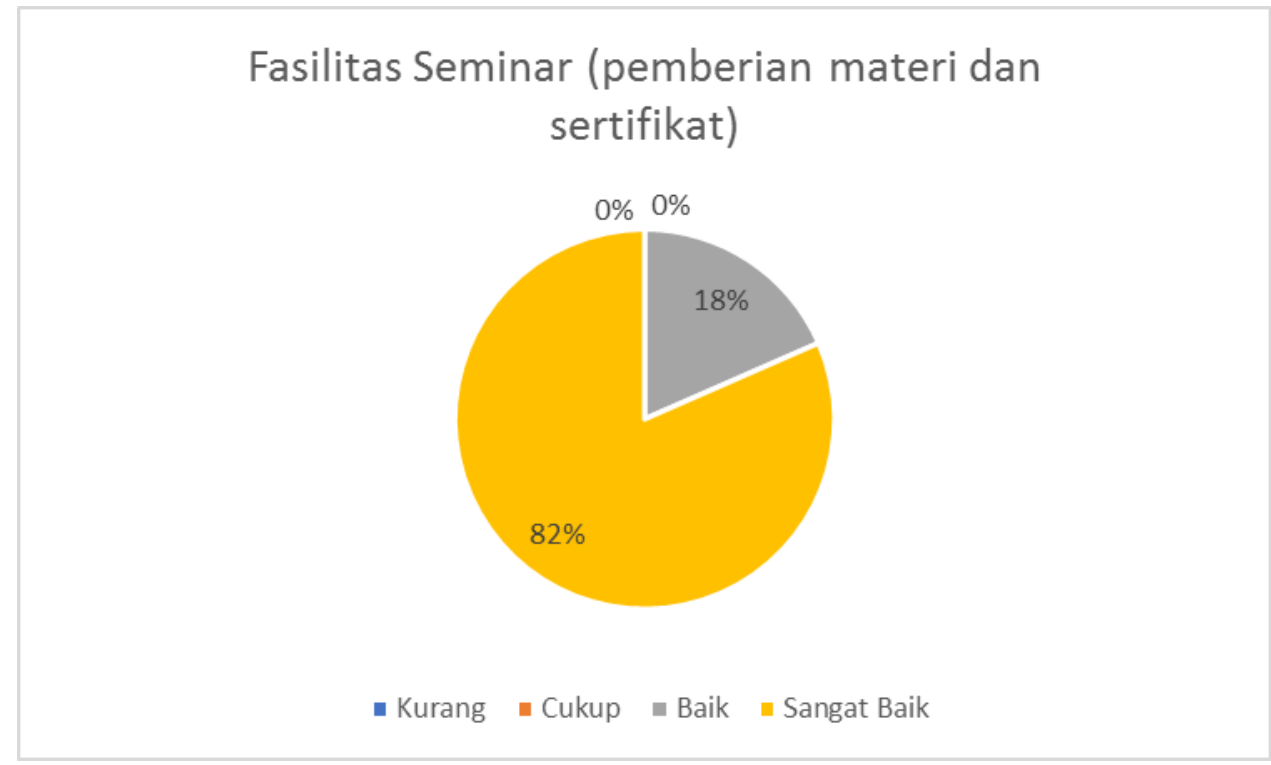

Gambar 3. Fasilitas Seminar

Pada gambar 4 berikut terlihat bahwa $86 \%$ peserta menilai bahwa materi yang diberikan oleh narasumber, tentang "Program Bermain Bersama Anak selama masa Pandemi Covid 19" sangat sesuai dengan harapan mereka.

\section{Kesesuaian Materi Dengan Harapan Peserta}

$0 ; 0 \% 0 ; 0 \%$

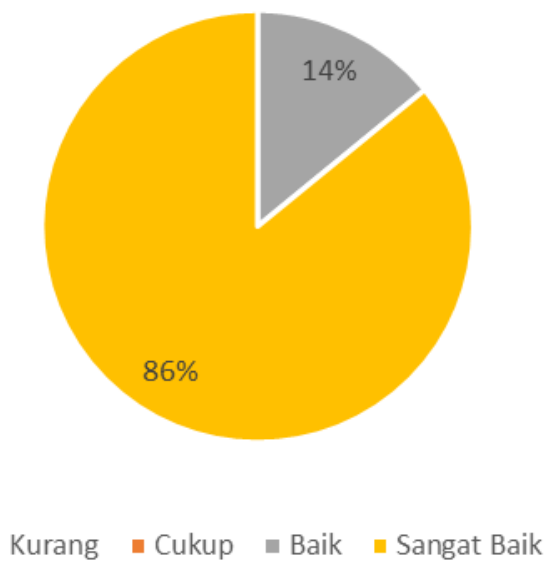

Gambar.5 Kesesuaian Materi dengan Harapan Peserta

Karena materi yang diberika sudah sesuai dengan harapan mereka, 98\% peserta berharap untuk dapat kembali mengikuti kegiatan jika panitia kembali mengadakan kegiatan serupa. 


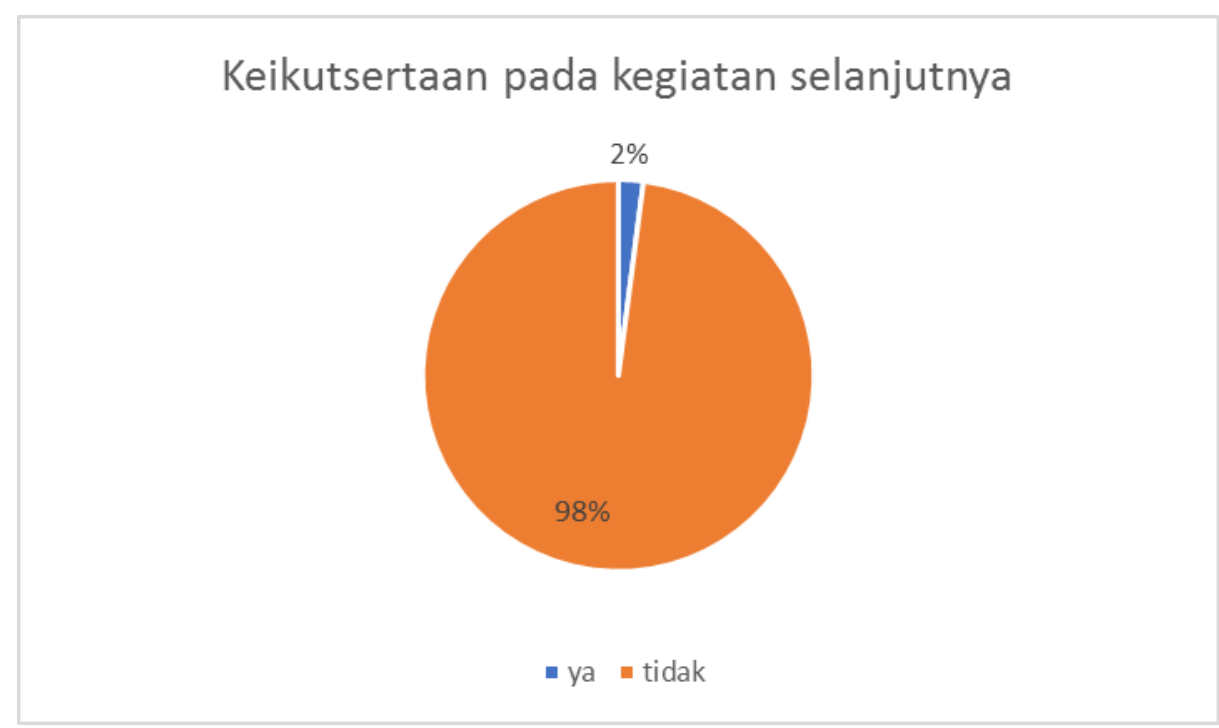

Gambar.6 Keikutsertaan Pada Kegiatan Selanjutnya

2) Reaksi Peserta Terhadap Pemateri, tujuannya adalah untuk mengetahui kepuasan peserta seminar online terhadap proses seminar online yang diberikan oleh pemateri, dikaji dari beberapa aspek pemateri, yaitu: a) materi pemaparan presentasi, b) isi materi, c)kesesuaian materi dengan issue, d) kebermanfaatan materi dan e) cara menjelaskan dari pemateri. Hal tersebut akan digambarkan pada penjelasan sebagai berikut ini.

Pertanyaan pertama terlihat pada gambar 7 mengenai materi pemaparan presentasi (power point). Para peserta menilai mulai dari baik (54\%) sampai sangat baik (46\%). Sehingga bisa dikatakan bahwa materi power point oleh pemateri sudah baik.

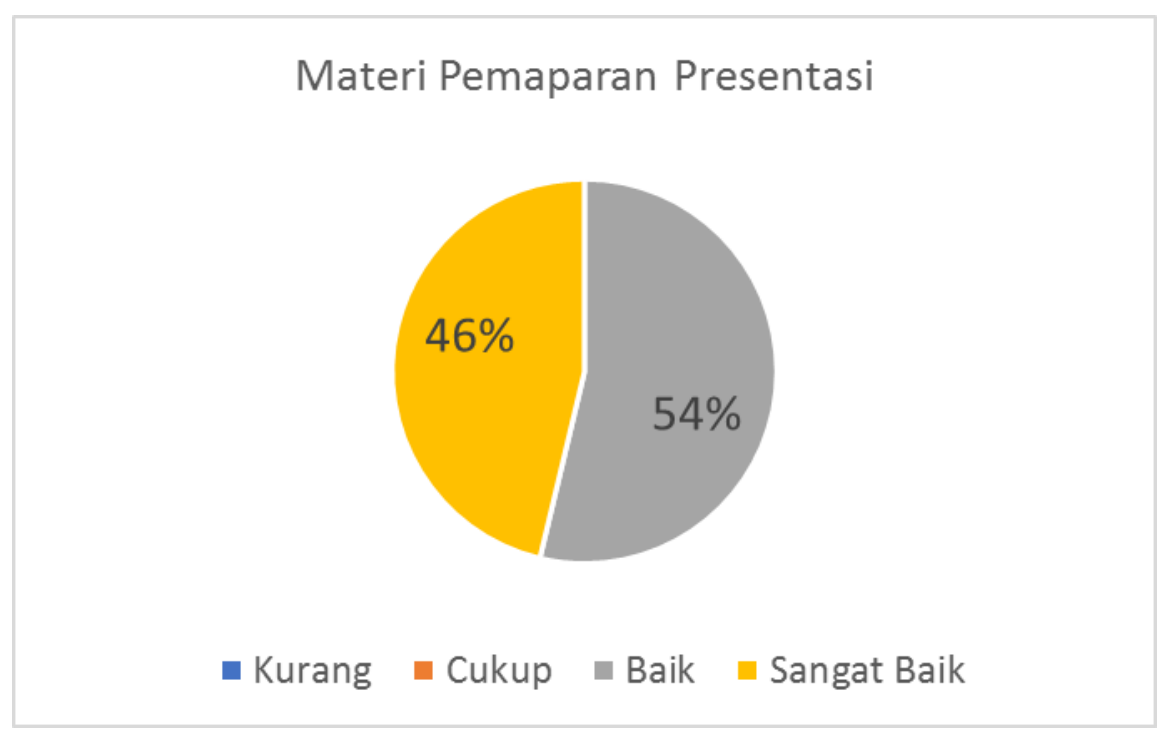

Gambar. 7 Materi Pemaparan presentasi

Pertanyaan kedua adalah mengenai isi materi yang diberikan. Isi materi yang diberikan adalah gabungan antara teori yang dibahasakan dengan popular beserta contoh-contoh yang relevan. Materi yang diberikan adalah mengapa anak harus dan perlu bermain, manfaat bermain untuk anak, kegiatan Ibu dan anak bermain bersama, 
merancang Program Bermain, bermain yang sesuai dengan DAP, apa saja Perinsip DAP, apa perinsip bermain adalah belajar, Domain belajar Bloom, bagaimana langkah-langkah membuat program bermain, dan bagaimana Langkah-langkah melakukan kegiatan bermain. Hal tersebut bisa kita lihat pada gambar 8 dibawah ini.

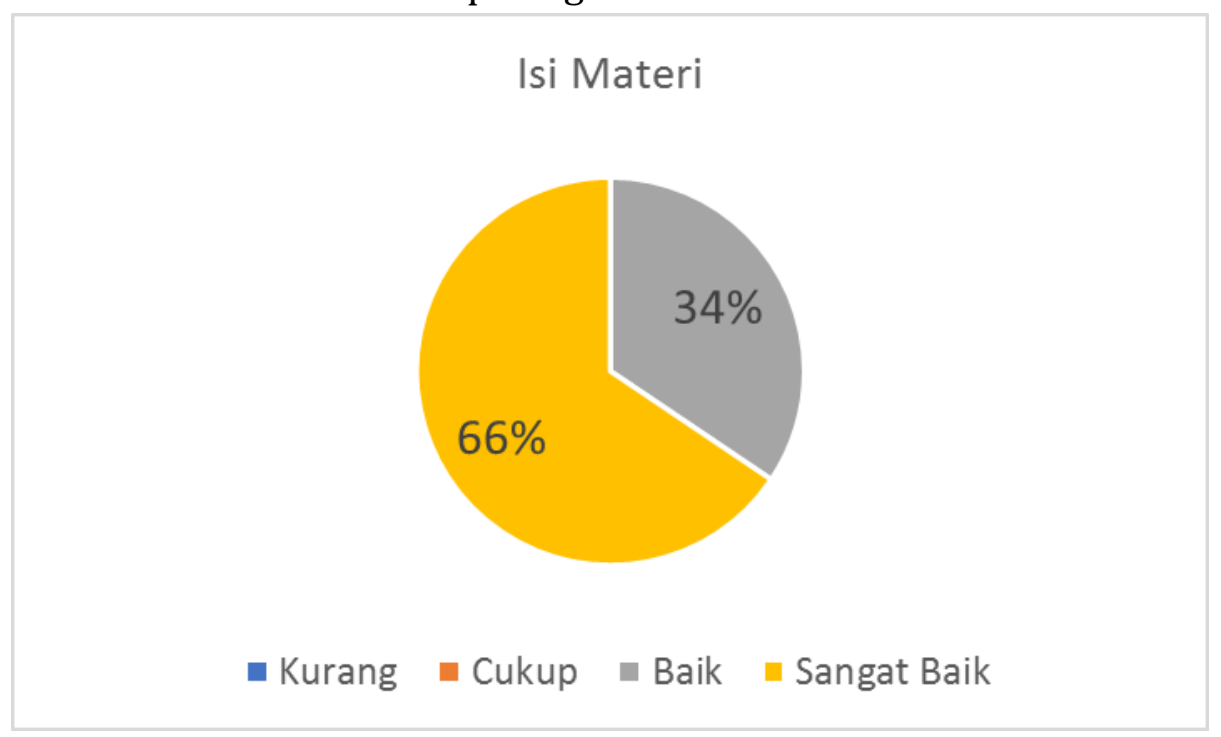

Gambar 8. Isi Materi.

Pertanyaan ke 3 adalah kesesuaian materi dengan issue. Artinya apakah materi yang diberikan sudah sesuai dengan fenomena yang terjadi saaat ini. 59\% peserta menilai materi sangat sesuai dengan issue dan kebutuhan saaat ini. Yaitu situasi pendemi covid-19, yang mengakibatkan semua harus bekerja, belajar dan beribadah dirumah saja. Seperti yang kita ketahui materi seminar online yang diberikan adalah bagaimana program bermain bersama anak selama dirumah saja, termasuk bagaimana cara merancang programnya, dan bagaimana untuk melakukannya.

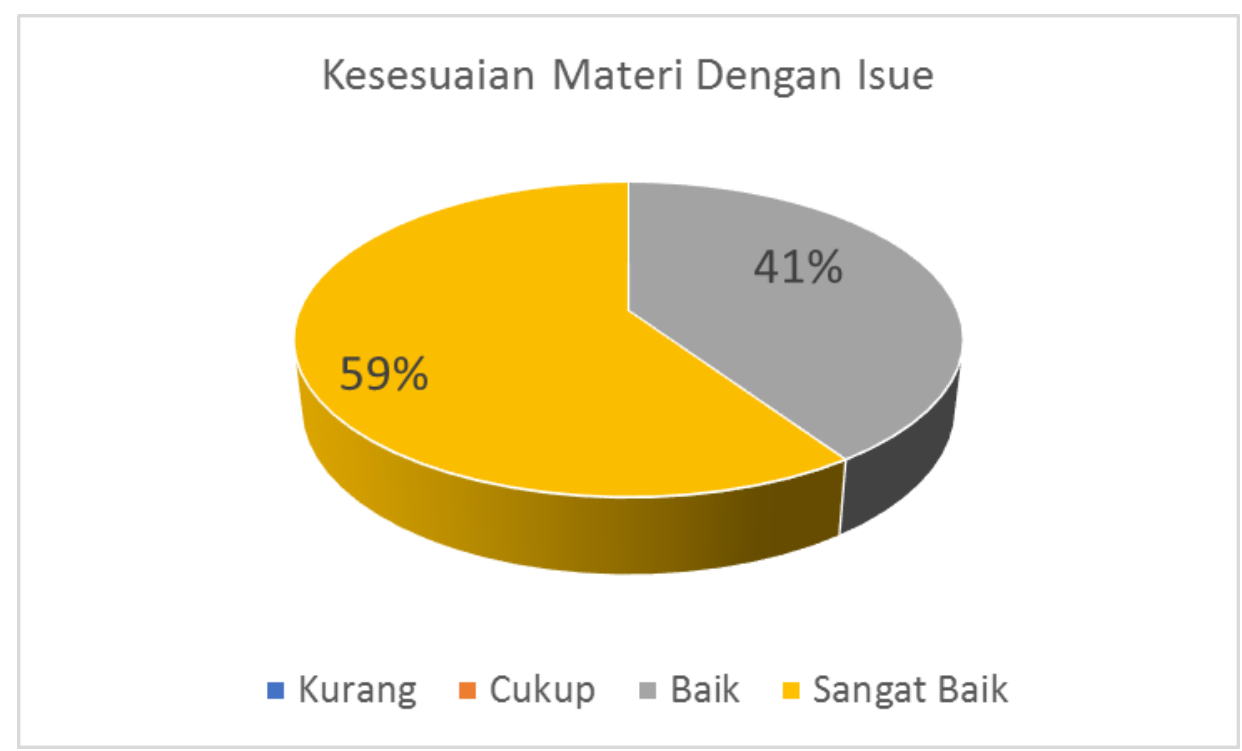

Gambar 9. Kesesuaian materi dengan issue

Pertanyaan kebermanfaat materi yang dijelaskan pada gambar 10 berikut ini mendapatkan $67 \%$ penilaian sangat baik, dan sisanya 33\% baik. Artinya para peserta 
menilai bahwa materi yang diberikan pada seminar on line ini sangat bermafaat untuk mereka.

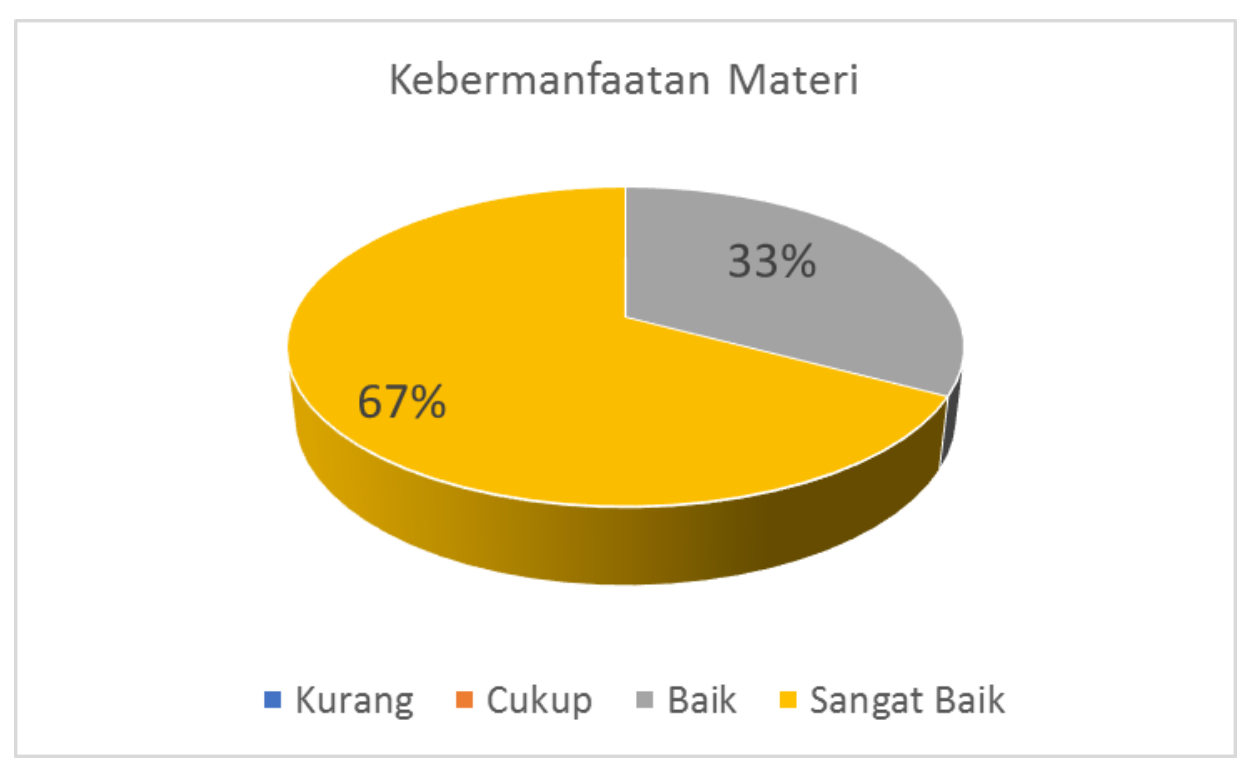

Gambar 10. Kebermanfaatan materi

Pertanyaan terakhir, pertanyaan ke 5 adalah bagaimana cara penyampaian yang diberikan oleh pemateri. Apakah cara menyampaikannya sulit dipahami, atau mudah dipahami. Untuk pertanyaan ini respon peserta adalah mulai dari mudah dipahami (50\%) sampai sangat mudah dipahami (50\%). Sehingga bisa dikatakan bahwa cara pemateri menyampaikan materi sudah baik sehingga mudah atau sangat mudah untuk dipahami.

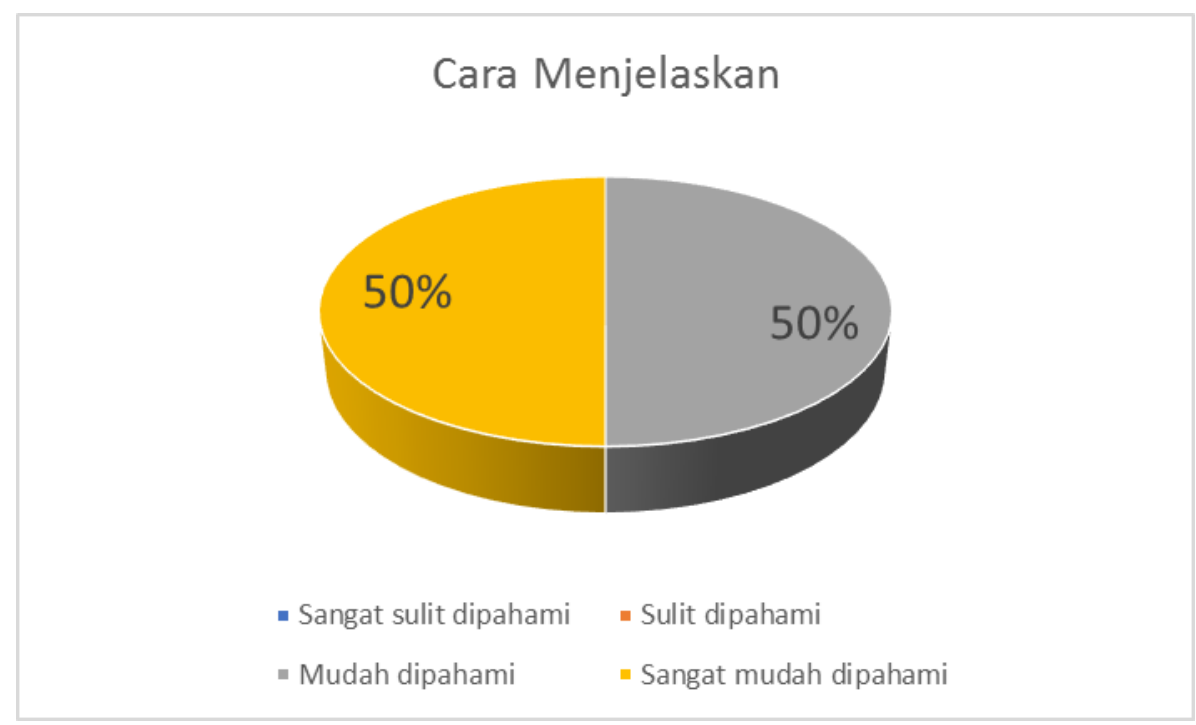

Gambar 11. Cara penyampaian pemateri

Dari uraian pertanyaan tentang reaksi pesera tentang pelaksaan kegiatan seminar nasional on line ini terlihat bahwa reaksi dari peserta adalah sangat positif. Hal ini dapat dilihat dari jawaban peserta yang tidak ada memberikan penilaian pada skala penilaian kurang. 


\section{Evaluasi level 2. Pengetahuan Peserta}

Dari 799 peserta, tidak semua peserta mengisi soal pre test dan post test. Hanya 244 orang peserta yang mengisinya. Soal pre test diberikan sehari sebelum kegiatan seminar online dilakukan. Pemberian soal dilakukan melalui google form pada whatsapp Group yang sudah dibuat pada saat pendaftaran. Materi soal yang diberikan adalah sesuai dengan materi seminar yang akan diberikan, yaitu mengapa anak harus bermain, manfaat bermain untuk anak, kegiatan Ibu dan anak bermain bersama, merancang Program Bermain, bermain yang sesuai dengan DAP, apa saja Perinsip DAP, apa perinsip bermain adalah belajar, Domain belajar Bloom, bagaimana langkah-langkah membuat program bermain, dan bagaimana Langkah-langkah melakukan kegiatan bermain. Dari hasil pre test rata-rata peserta yang menjawab benar ada 61\%. Sedangkan rata-rata hasil post test peserta yang menjawab benar ada 77\%. Sehingga terjadi kenaikan jumlah peserta yang menjawab dengan benar sebanyak 16\%. Pada pre test soal yang paling sedikit jumlah peserta yang menjawab dengan benar adalah soal nomor 8 , yaitu tentang bagaimana cara membuat program bermain bersama anak, dimana hanya $45 \%$ dari total peserta yang menjawab dengan benar. Begitu juga dengan hasil post test. Jumlah peserta yang menjawab dengan benar pada soal no 8 masih paling rendah yakni 54\% saja peseta yang menjawab dengan benar. Artiya soal no 8, mengenai bagaimana membuat program bermain bersama anak mempunyai kenaikan jumlah peserta yang menjawab dengan benar hanya 9\%. Dan memang soal nomor 8 merupakan inti materi seminar ini. Sedangkan soal yang paling banyak dijawab peserta dengan benar adalah soal nomor 1 , yaitu materi mengapa anak oerlu dan harus bermain. Soal nomor 1 juga merupakan soal yang paling tinggi kenaikan jumlah peserta yang menjawab dengan benar. Mengalami kenaikan 30\%, dari jumlah peserta yang benar 67\% menjadi 97\%. Dengan kata lain hampir $100 \%$ peserta akhirnya bisa menjawab dengan benar mengapa anak perlu dan harus bermain. Materi ini adalah konsep dasar dari arti bermain bagi anak.

\begin{tabular}{clccc}
\hline \multirow{2}{*}{$\begin{array}{c}\text { No } \\
\text { Soal }\end{array}$} & \multicolumn{1}{c}{ Topik Materi } & \multicolumn{3}{c}{ \% Jawaban Yang Benar } \\
\cline { 2 - 5 } & Mengapa anak perlu bermain & $67 \%$ & $97 \%$ & $30 \%$ \\
\hline 1 & $\begin{array}{l}\text { Pre test } \\
\text { "Hak anak untuk beristirahat dan } \\
\text { bersantai, bermain dan turut serta } \\
\text { dalam kegiatan-kegiatan rekreasi } \\
\text { yang sesuai dengan usia anak dan } \\
\text { untuk turut serta secara bebas } \\
\text { dalam kehidupan budaya dan seni" }\end{array}$ & $49 \%$ & $69 \%$ & $20 \%$ \\
\hline 3 & $\begin{array}{l}\text { Ranah/domain tujuan dalam } \\
\text { belajar, Taxonomy Bloom }\end{array}$ & $50 \%$ & $64 \%$ & $14 \%$ \\
\hline 4 & Manfaat bermain bagi anak & $76 \%$ & $90 \%$ & $14 \%$ \\
\hline 5 & $\begin{array}{l}\text { Manfaat bermain bersama ibu dan } \\
\text { anak }\end{array}$ & $80 \%$ & $94 \%$ & $14 \%$ \\
\hline 6 & $\begin{array}{l}\text { Perinsip Pembelajaran untuk anak } \\
\text { sesuai DAP }\end{array}$ & $48 \%$ & $67 \%$ & $19 \%$ \\
\hline 7 & $\begin{array}{l}\text { Contoh kegiatan berada pada } \\
\text { domain }\end{array}$ & $51 \%$ & $63 \%$ & $12 \%$ \\
\hline
\end{tabular}




\begin{tabular}{clccc}
\hline 8 & $\begin{array}{l}\text { Bagaimana membuat program } \\
\text { bermain }\end{array}$ & $45 \%$ & $54 \%$ & $9 \%$ \\
\hline 9 & $\begin{array}{l}\text { Langkah kegiatan membuat } \\
\text { program bermain bersama anak }\end{array}$ & $67 \%$ & $86 \%$ & $19 \%$ \\
\hline 10 & $\begin{array}{l}\text { Hal penting yang harus dilakukan } \\
\text { saat bermain bersama anak }\end{array}$ & $72 \%$ & $85 \%$ & $13 \%$ \\
\hline & $61 \%$ & $77 \%$ & $16 \%$ \\
\hline
\end{tabular}

Tabel 1. Persentase peserta yang menjawab dengan benar

Sedangkan peningkatan pengetahuan peserta yang diperoleh dari hasil pre test dan juga post test dapat digambarkan pada gambar 12 berikut ini.

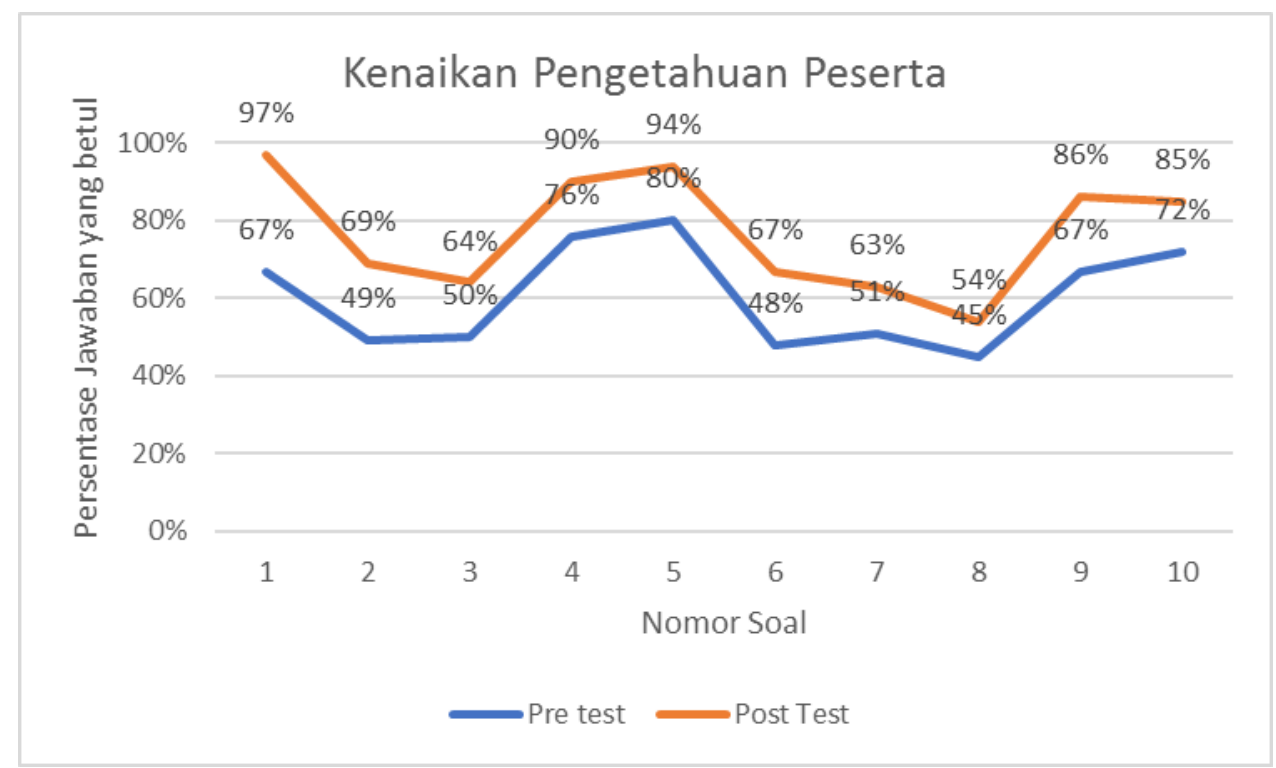

Gambar 12. Kenaikan tingkat pengetahuan peserta

\section{KESIMPULAN}

Dari hasil penelitian evaluasi kegiatan seminar nasional on line ini didapatkan bahwa reaksi peserta sangat positif. Penilaian pada level 1, Reaksi peserta, terkait dengan: 1) Penyelenggaraan, meliputi (a) kepesertaan, seperti kejelasan informasi kegiatan, kemudahan akses kepesertaan (b) kepanitiaan, manajemen waktu kegiatan(c) akomodasi: pemberian materi seminar, sertifikat, dan kesesuaian materi dengan harapan, 2) Pemateri, meliputi a) materi pemaparan presentasi, b) isi materi, c)kesesuaian materi dengan issue, d) kebermanfaatan materi dan e) cara menjelaskan dari pemateri. Hampir semua peserta ingin mengikuti jika diselenggarakan kegiatan selanjutnya. Sedangkan hasil pada level 2, pengetahuan peserta dari materi, hasil perbandingan pre test dan post test terhadap materi seminar didapatkan peningkatan pengetahuan para peserta tentang bermain bersama anak dirumah rata-rata sebesar $16 \%$. 


\section{PENGHARGAAN}

Terimakasih kepada Prodi Pendidikan Guru Pendidikan Anak Usia Dini, Fakultas ilmu Pendidikan, Universitas Muhammadiyah Jakarta, dan juga yayasan Gema Anak Indonesia yang sudah memfasilitasi untuk terselenggaranya kegiatan seminar on line ini. Juga kepada para peserta yang sudah meluangkan waktu akhir pekannya dengan bergabung dan melengkapi kebutuhan administrasi kegiatan.

\section{REFERENSI}

[1] D. A. Sari, R. N. Mutmainah, I. Yulianingsih, T. A. Tarihoran, and M. Bahfen, “Kesiapan Ibu Bermain Bersama Anak Selama Pandemi Covid-19,'Dirumah Saja,'” J. Obs. J. Pendidik. Anak Usia Dini, vol. 5, no. 1, pp. 475-489, 2020.

[2] D. A. Sari, "Children's Gross Motor: After-school Activities And Mother's Role at Home (A Survey Study of Kindergarten Group A, at Pondok Aren District, Tangerang Selatan, Banten Province, Indonesia)," 2016, pp. 494-499.

[3] C. N. Irma, K. Nisa, and S. K. Sururiyah, "Keterlibatan Orang Tua dalam Pendidikan Anak Usia Dini di TK Masyithoh 1 Purworejo," J. Obs. J. Pendidik. Anak Usia Dini, vol. 3, no. 1, p. 214, 2019.

[4] J. Barlow and E. Coren, "The Effectiveness of Parenting Programs," Res. Soc. Work Pract., vol. 28, no. 1, pp. 99-102, Jan. 2018.

[5] E. Oktavianto, K. Karimah, E. Timiyatun, and A. Badi'ah, "Pelatihan bermain pada ibu meningkatkan kelekatan anak,” MEDISAINS, vol. 16, no. 3, p. 120, Jan. 2019.

[6] Haerudin et al., "Peran Orang Tua Dalam Membimbing Anak Selama Pembelajaran di Rumah Sebagai Upaya Memutus Covid-19," Karawang, Univ. Singaperbangsa, pp. 1-12, 2020.

[7] N. Rohmah, "Bermain dan pemanfaatannya dalam perkembangan anak usia dini," Tarbawi J. Pendidik. Islam, vol. 13, no. 2, 2016.

[8] N. Rahmadianti, "Pemahaman Orang Tua Mengenai Urgensi Bermain Dalam Meningkatkan Perkembangan Sosial Anak Usia Dini," EARLY Child. J. Pendidik., vol. 4, no. 1, pp. 57-64, Jul. 2020.

[9] E. Kurniati, D. K. Nur Alfaeni, and F. Andriani, "Analisis Peran Orang Tua dalam Mendampingi Anak di Masa Pandemi Covid-19," J. Obs. J. Pendidik. Anak Usia Dini, vol. 5, no. 1, p. 241, May 2020.

[10] D. Kirkpatrick and J. Kirkpatrick, Evaluating training programs: The four levels. Berrett-Koehler Publishers, 2006. 